\title{
ASSESSMENT OF RADIOACTIVITY LEVELS AND TRANSFER \\ FACTOR OF NATURAL RADIONUCLIDES AROUND IRON AND STEEL SMELTING COMPANY LOCATED IN FASHINA VILLAGE, ILE-IFE, OSUN STATE, NIGERIA
}

\author{
UDC 539.16(669)
}

\section{Samuel Oluwafisayo Oluyide ${ }^{1}$, Pascal Tchokossa ${ }^{1}$, Fisayo Cornelus Akinyose ${ }^{1}$, Muyiwa Michael Orosun ${ }^{2}$}

${ }^{1}$ Department of Physics, Obafemi Awolowo University, Ile-Ife, Osun State, Nigeria

${ }^{2}$ Department of Physics, University of Ilorin, Kwara State, Nigeria

\begin{abstract}
This study assessed the radioactivity levels and transfer factor of natural radionuclides around iron and steel smelting company located in Fashina village, Ile-Ife, Osun State, Nigeria. This was with a view to evaluate the exposure rate of the study area, determine the radionuclides present and activity concentration $(238 \mathrm{U}$ and $232 \mathrm{Th}$ and $40 K)$ in the samples and evaluate the soil-to-food transfer ratio of the radionuclides. A portable survey meter with a Global Positioning System (GPS) were used for in-situ investigation and a well-calibrated $\mathrm{NaI}(\mathrm{Tl})$ detector system was used for the radioactivity measurement of the samples. A total of 38 samples comprising soil, food and water were collected at the study area (Fashina) and control area (Opa) in Osun state, Nigeria for spectrometry analysis. The soil and food samples were oven dried, pulverized and sieved while water samples were acidified with $10 \mathrm{~mL}$ of $11 \mathrm{M} \mathrm{HCl}$ per litre to prevent adsorption of radionuclides with the wall of the container. All the samples were then sealed and kept for at least 28 days in radon impermeable cylindrical container so as to reach secular equilibrium. The mean exposure rates in the study area were $0.14 \mu \mathrm{Sv} \mathrm{hr}-1$ and $0.12 \mu \mathrm{Sv}$ hr-1 for the control environment. The mean radioactivity content obtained for $238 \mathrm{U}, 232 \mathrm{Th}$ and $40 \mathrm{~K}$ were $12.14 \pm 4.17 \mathrm{~Bq} \mathrm{~kg}-1,23.23 \pm 7.67 \mathrm{~Bq} \mathrm{~kg}-1$ and $270.14 \pm$ $61.79 \mathrm{~Bq} \mathrm{~kg}-1$ respectively in soil samples and $8.56 \pm 2.80 \mathrm{~Bq} \mathrm{~kg}-1,13.17 \pm 4.48 \mathrm{~Bq} \mathrm{~kg}-1$ and $89.41 \pm 24.15 \mathrm{~Bq} \mathrm{~kg}-1$ respectively in food samples. Similarly it was $7.64 \pm 2.95 \mathrm{~Bq}$ $L-1,10.04 \pm 3.43 \mathrm{~Bq} L-1$ and $69.04 \pm 15.49 \mathrm{~Bq} \mathrm{~L}-1$ respectively for $238 \mathrm{U}, 232 \mathrm{Th}$ and $40 \mathrm{~K}$ in water samples. The transfer factor from soil to food for $238 \mathrm{U}$, 232Th and $40 \mathrm{~K}$ were calculated from the activity concentrations of soil and food, while the means were 0.73 , 0.61 , and 0.39 respectively in the study area.
\end{abstract}

Key words: radioactivity, scrap metal, transfer factor, gamma spectrometry, gamma-scout

Received January 15, 2018 / Accepted December 28, 2018

Corresponding author: Muyiwa M. Orosun

University of Ilorin, Ilorin, Kwara State, Nigeria

E-mail: muyiwaorosun@yahoo.com 


\section{INTRODUCTION}

Iron and steel scrap recycling has been of double advantage to Nigeria in terms of its contribution to secondary steel smelting. The scrap is both a raw material source and a waste management method for handling materials that would have otherwise constituted various forms of environmental hazards into useful forms (Owoade et al., 2015; Orosun et al., 2016b).This rapid growth has not been matched with the required strict regulations for environmental and personnel protection. Most of these industries are yet to invest in facilities necessary for improving their production processes. These industries also lack installed control devices (scrap metal radiation) on their production processes as should be required. Radioactively contaminated scrap threatens human health and the environment, as well as economics of the steel industry. If radioactive scrap contaminate the metal supply, it could expose steel workers, the environment to health hazard and potentially be incorporated into consumer products (EPA, 2015). Emissions, which include a range of air pollutants associated with the iron smelter production processes has remained a great concern (Brook et al., 2004; UNECE, 2006; Pope and Dockery, 2006; Zhang et al., 2009; Owoade et al., 2009; Tai et al., 2010; Orosun et al., 2016b). Contamination of the food chain occur as a result of direct deposition of these radionuclides on plant leaves, fruits, tubers, root uptake from contaminated soil or water, and animals ingesting contaminated plants, soil or water(Velasco et al., 2004).

According to IAEA (2004), radioactive scrap metals is defined as metals that comprise radioactively contaminated scrap metal, activated scrap metal and scrap metal with radioactive source(s) or substances contained within it. Radioactive scrap metal can occur in a number of different ways; demolition or decommissioning of industrial facilities processing raw materials containing naturally occurring radionuclides, decommissioning of nuclear installations (such as nuclear power plants or nuclear fuel cycle facilities) and other facilities, loss of sources, demolition of facilities in which radioactive sources have been used and incorporation of old radioactive devices into scrap. The major naturally occurring radionuclide includes the isotopes of uranium and thorium plus their daughters and potassium (IAEA, 1989) which are categorized into primordial, secondary and cosmogenic radionuclides. The pathways by which people are exposed to radiation result in exposure to different parts of the body which are via inhalation, ingestion and direct exposure.

The iron and steel company along Ife-Ibadan road is involved in the recycling of secondary steel metals which release various particles that may be associated with radioactive contaminants. These emissions do not only degrade the soil, vegetation and water, but also increase the rate of occurrence of some common diseases in the populace. This study is therefore necessary to investigate the activities content and transfer factor of natural radionuclides in soil, food and water samples in the residential areas and farms around the iron and steel smelting company.

\section{MATERIALS AND METHODS}

\subsection{The study area}

The study area (Fashina) is located in Ife Central Local Government Area of Osun State, Southwest Nigeria on latitude $7^{\circ} 27^{\prime \prime} \mathrm{N}$ and $7^{\circ} 37^{\prime \prime} \mathrm{N}$ and longitude $4^{\circ} 22^{\prime} \mathrm{E}$ and $4^{\circ} 29^{\prime \prime} \mathrm{E}$ where the iron and steel company is located. This company, since January 2011, is specializing in the 
use of electric arc furnace in the production of iron bar from the scrap collected from various dumping area across the country. The climate of this area is humid tropical characterized by marked wet and dry season typical south-west of Nigeria. The rainy season covers a period of seven to nine months with two high rainfall peaks and a short dry season. The mean annual rainfall recorded from meteorological station in Teaching and Research Farm of Obafemi Awolowo University, Ile-Ife, for this area is about $1196 \mathrm{~mm}$ and may be higher due to orographic effect. The dry season is associated with the tropical continental air mass with a severe harmattan wind that carries a lot of dust towards the end of the dry season and this season covers a period of four to six months. The control area (Opa) was located in the same Local Government on latitude $7^{\circ} 32^{\prime \prime} \mathrm{N}$ and $7^{\circ} 34^{\prime \prime} \mathrm{N}$ and longitude $4^{\circ} 32^{\prime \prime} \mathrm{E}$ and $4^{\circ} 35^{\prime \prime} \mathrm{E}$ under the same climatic conditions and about $12 \mathrm{~km}$ ( 7 miles) from the study area.

\subsection{Sampling}

It has been noted that the selection of an adequate number of properly located sampling sites is of great importance in obtaining meaningful data (Fitzgerald, 1969). At the study area, a total number of thirty (30) samples were collected radially around the factory, especially in the cultivated lands while eight (8) samples were collected in Opa area as controls for this case study. The samples comprise of soil, vegetables, fresh cassava, grains and water of different sources such as well, borehole, stream and rain water during and after the factory production time. All water samples were treated with acidified hydrochloric acid $(11 \mathrm{M})$ at the rate of $10 \mathrm{~mL}$ per litre of sample to avoid adsorption of radionuclides on the walls of the container. Each soil sample and its derived food product were collected by mapping out 1 by $1 \mathrm{~m} 2$ at each sampling point. In each sampling square, five core soil samples were taken (four from all the corners and one from the centre) at the depth of 0-30 $\mathrm{cm}$ using a hand towel, while its derived food products were also collected within the same sample square point. All the five core soil samples were mixed together to make a composite sample, labelled appropriately after individual placement in polythene bags in order to avoid any mix-up as well as cross contamination. The collected samples were then transported to the laboratory for further processing. The descriptions of the various samples as well as geological survey of the study area are shown in Figure 1 below. Samples received in the laboratory may not be in the proper physical form for analysis. They may require reduction in size, dryness or some form of homogeneity before aliquots can be taken for analysis. The solid samples were oven-dried at $85 \mathrm{oC}$ until a constant weight is attained, then ground and passed through a mesh size of $2 \mathrm{~mm}$ while the larger particles were discarded. All the samples were thoroughly washed with dilute HNO3, rinsed with distilled water, labelled and sealed in cylindrical air tight polyvinylchloride containers and stored for 28 days to attain secular equilibrium. Then the gamma spectrometry measurements of the samples were carried out using a well calibrated Sodium Iodide (NaI(TI)) detector at the Centre for Energy Research Development (CERD), Obafemi Awolowo University, Ile-Ife, Osun state, Nigeria.

\subsection{Instrumentations}

Measurements were carried out with Gamma-Scout radiation detector with Serial Number: 038439 as a dose meter to measure the exposure rate of the environments of each sample in the study area. Garmin Global Positioning System (GPS) device was used to get the location of each sample point. Waypoints which are the co-ordinates of a specific 
location were created base on the locations, recorded and stored on the device. The activity concentration of the natural radionuclides in food, water and soil samples were determined using a well calibrated $76 \mathrm{~mm} \times 76 \mathrm{~mm} \mathrm{NaI}(\mathrm{TI})$ detector shielded from radiation by a $5 \mathrm{~cm}$ thick Lead shield located at the Centre for Energy Research and Development (CERD), Obafemi Awolowo University, Ile-Ife, Nigeria. Accurate energy and efficiency calibrations of the gamma spectrometry system were made using a standard source of radionuclides supplied by the International Atomic Energy Agency (IAEA), Vienna, Austria and the isotope products laboratories, Burbank laboratory, California, U.S.A. The system was preset to 18000 seconds (counting time). When this counting time was reached, the information about the radionuclides at different photo peaks were displayed, recorded and stored in the computer. The gamma spectroscopy analysis was carried out by a spectra-analysis program, SAMPO 90, which matched the gamma energies at various energy levels to a library of possible isotopes. An empty container with the same geometry as that of the sample was counted for background. The net background peak was subtracted from the corresponding net peak area for a particular radionuclide. The activities concentrations for the natural radionuclides in the measured samples were evaluated using the following equation;

$$
C_{s m}=\frac{A_{s m}-A_{o}}{P_{\gamma} M_{s m} t \varepsilon}
$$

where, $\mathrm{A}_{\mathrm{sm}}=$ the net area of the peak in the sample, $\mathrm{A}_{\mathrm{o}}=$ the net area of the background peak, $\mathrm{t}=$ the counting time in seconds, $\mathrm{M}_{\mathrm{sm}}=$ mass of the sample, $\varepsilon=$ the detection efficiency at the energy line and $\mathrm{P}_{\gamma}=$ the gamma yield.

The specific activity of the radioisotope is obtained by direct comparison with the same radionuclide in a given standard. The specific radioactivity " $\mathrm{Cx}$ " in the sample and the corresponding specific radioactivity "Cs" in the standard are related by

$$
C_{x}=C_{s} \frac{M_{s} A_{x}}{M_{x} A_{s}}
$$

where, $M_{s}=$ mass of the standard, $M_{x}=$ mass of the sample, $A_{s}=$ area of the standard and $\mathrm{A}_{\mathrm{x}}=$ area of the sample.

\subsection{Transfer factor evaluation from soil to food}

The transfer factor (TF) for food which is an index for the accumulation of radionuclides by plants from soil to plants according to IAEA (1982) is defined as:

$$
\mathrm{TF} \text { food }=\frac{\text { Activity Concentration in Food }(\mathrm{Bq} / \mathrm{kg})}{\text { Activity Concentration in Soil }(\mathrm{Bq} / \mathrm{kg})}
$$

There are two main mechanisms for the contamination of vegetation i.e. by root uptake directly and by aerial deposition of fallout radionuclides on plants. 


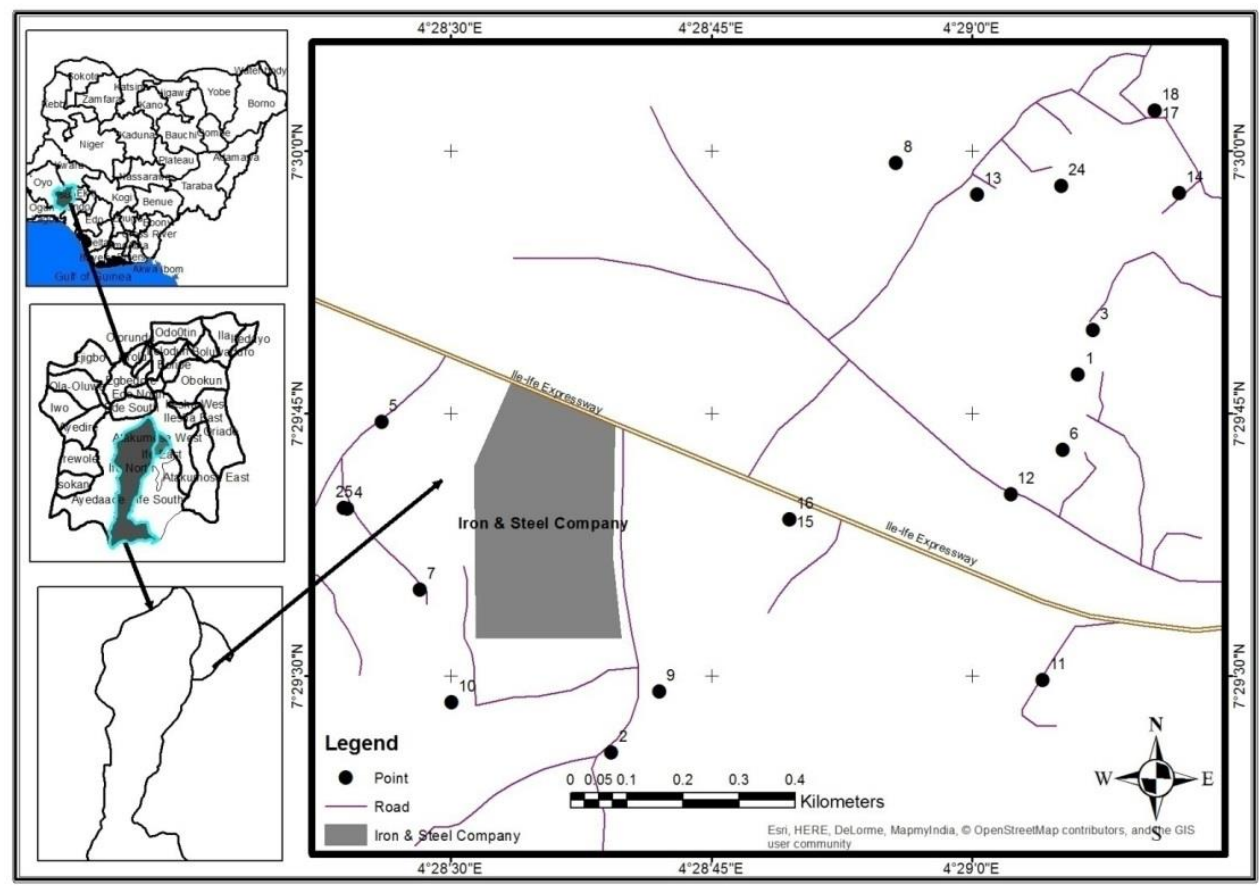

Fig. 1 Samples Locations at Fashina Village.

\section{RESULTS AND DISCUSSION}

\subsection{In-situ Measurement}

The results of the in-situ survey are presented in Table 1 and illustrated in figure 2 for the study and control environments. The values ranged between 0.11 to $0.16 \mu \mathrm{Sv}$ h- 1 with an average of $0.14 \mu \mathrm{Sv} h-1$ in the study area while the control site have values ranging between 0.10 to $0.14 \mu \mathrm{Sv}$ h-1 with an average value of $0.12 \mu \mathrm{Sv} h-1$. The average value in study area (Fashina) was higher than the control area; hence this can be as a result of industrial activities present in the study area. Most of the values estimated for the exposure rate in the study area were higher than the recommended limit of $0.11 \mu \mathrm{Sv} \mathrm{hr}-1$ (IAEA, 2000). The average value of $0.14 \mu \mathrm{Sv} \mathrm{h}$ - in this study is higher than the recommended limit (Larmash, 1983). 
Table 1 Radiation level measurement in soil, food and water samples by gamma scout

\begin{tabular}{|c|c|c|c|c|}
\hline $\mathrm{S} / \mathrm{N}$ & Code & $\begin{array}{c}\text { Sample } \\
\text { points }\end{array}$ & $\begin{array}{c}\text { Exposure rate } \\
\left(\mu \mathrm{Sv} \mathrm{hr}^{-1}\right)\end{array}$ & Description \\
\hline 1 & VSo1 & 5 & 0.15 & Water Leaves@ @ashina 1 \\
\hline 2 & VSo2 & 6 & 0.16 & Water Leaves @ Fashina 2 \\
\hline 3 & VSo3 & 1 & 0.12 & Cassava@ Fashina 1 \\
\hline 4 & VSo4 & 2 & 0.16 & Cassava@ Fashina 2 \\
\hline 5 & VSo5 & 10 & 0.16 & Cassava for processed Garri @ Fashina \\
\hline 6 & VSo6 & 7 & 0.14 & Jute leaves (Ewedu) @ Fashina 1 \\
\hline 7 & VSo7 & 8 & 0.15 & Jute Leaves (Ewedu) @Fashina 2 \\
\hline 8 & VSo8 & 3 & 0.14 & African Spinach (Efotete) @ Fashina 1 \\
\hline 9 & VSo9 & 4 & 0.15 & African Spinach (Efotete) @ Fashina 2 \\
\hline 10 & VSo10 & 9 & 0.12 & Dried Yellow Maize @ Fashina \\
\hline 14 & WS01 & 13 & 0.12 & Borehole Water @ Fashina 1 \\
\hline 15 & WS02 & 14 & 0.14 & Borehole Water@Fashina 2 \\
\hline 16 & WS03 & 11 & 0.11 & Stream Water @ Fashina 1 \\
\hline 17 & WS04 & 12 & 0.13 & Stream Water@ $@$ Fashina 2 \\
\hline 18 & WS05 & 24 & 0.14 & Well Water@ @ashina 1 \\
\hline 19 & WS06 & 25 & 0.12 & Well Water@ $@$ Fashina 2 \\
\hline 20 & WS07 & 15 & 0.14 & Rain Water No Production (NP) Fashina 1 \\
\hline 21 & WS08 & 17 & 0.12 & Rain Water Production (P) @ Fashina 2 \\
\hline 22 & WS09 & 16 & 0.12 & Rain Water Production (P) @ Fashina 1 \\
\hline 23 & WS010 & 18 & 0.12 & Rain Water No Production (NP) @ Fashina 2 \\
\hline 21 & WS08 & 17 & 0.12 & Rain Water Production (P) @ Fashina 2 \\
\hline 22 & WS09 & 16 & 0.12 & Rain Water Production (P) @ Fashina 1 \\
\hline 23 & WS010 & 18 & 0.12 & Rain Water No Production (NP) @ Fashina 2 \\
\hline 26 & Soo1 & 5 & 0.15 & Sandy soil for water leaves @ Fashina 1 \\
\hline 27 & Soo2 & 6 & 0.16 & Sandy soil for water leaves @ Fashina 2 \\
\hline 28 & Soo3 & 1 & 0.12 & Sandy soil for cassava plant @ Fashina 1 \\
\hline 29 & Soo4 & 2 & 0.16 & Sandy soil for cassava plant @ Fashina 2 \\
\hline 30 & Soo5 & 10 & 0.16 & Sandy soil for Cassava processed garri @ Fashina \\
\hline 31 & Soo6 & 7 & 0.14 & Sandy soil for jute leaves (Ewedu) @ Fashina 1 \\
\hline 32 & Soo7 & 8 & 0.15 & Sandy soil for jute leaves (Ewedu) @Fashina 2 \\
\hline 33 & Soo8 & 3 & 0.14 & Sandy soil for African spinach (Efotete) @ Fashina 1 \\
\hline 34 & Soo9 & 4 & 0.15 & Sandy soil for African spinach (Efotete) @ Fashina 2 \\
\hline \multirow[t]{2}{*}{35} & Soo10 & 9 & 0.12 & Sandy soil for dried yellow maize @ Fashina \\
\hline & Mean & & 0.14 & \\
\hline 11 & VSo11 & 21 & 0.14 & Water Leaves@Opa \\
\hline 12 & VSo12 & 19 & 0.10 & Dried White Maize @Opa \\
\hline 13 & VSo13 & 20 & 0.12 & Jute leaves (Ewedu)@ Opa \\
\hline 24 & WS011 & 22 & 0.12 & Well Water@ Opa \\
\hline 25 & WS012 & 23 & 0.10 & Borehole Water@Opa \\
\hline 36 & Soo11 & 21 & 0.14 & Sandy soil for water leaves @ $O p a$ \\
\hline 37 & Soo12 & 19 & 0.10 & Sandy soil for dried white maize @ $O p a$ \\
\hline \multirow[t]{2}{*}{38} & Soo13 & 20 & 0.12 & Sandy soil for jute leaves (Ewedu) @ Opa \\
\hline & Mean & & 0.12 & \\
\hline
\end{tabular}




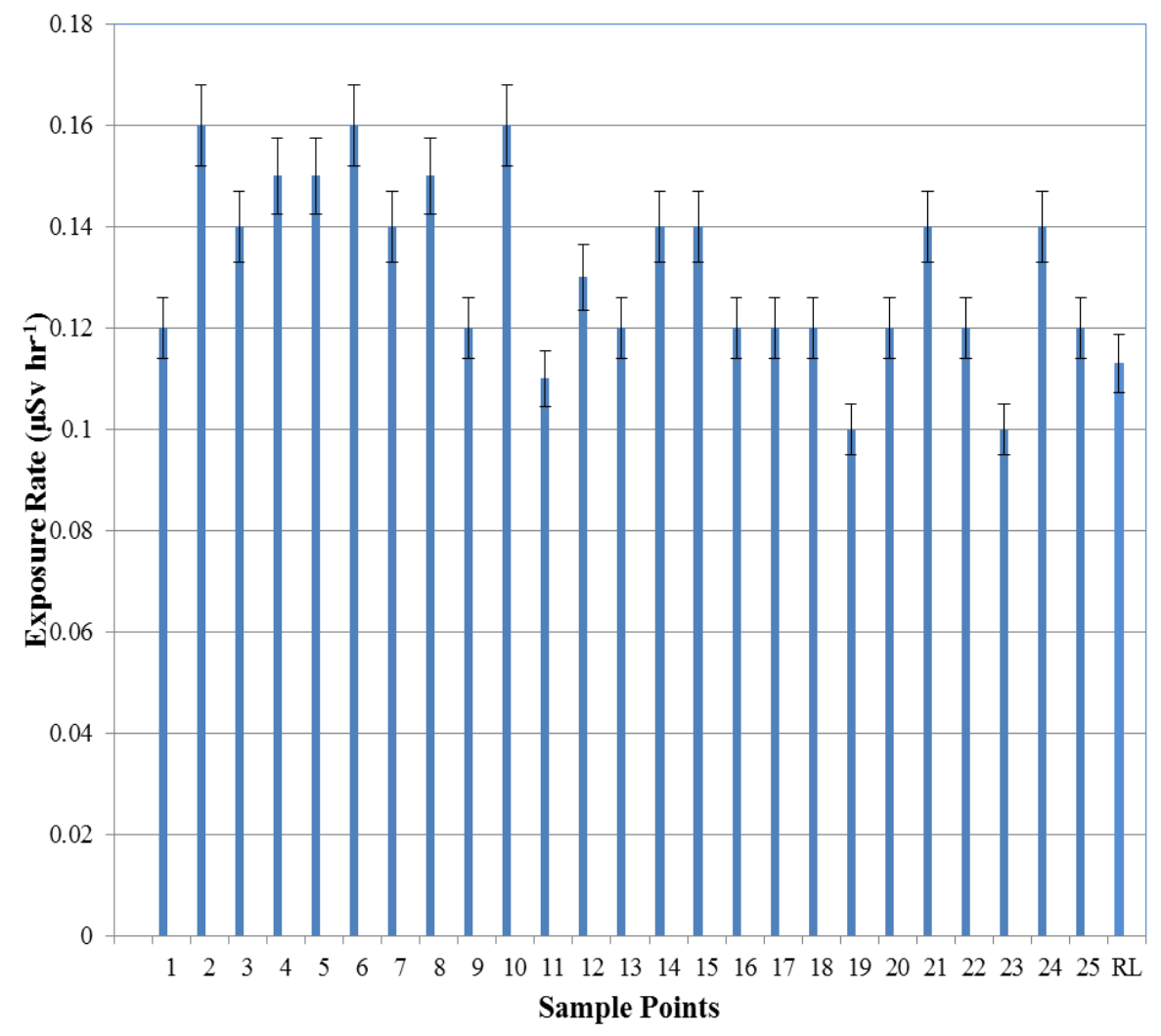

Fig. 2 Exposure rate of the study environment

Key:RL: Recommended limit by IAEA (2000)

\subsection{Activity concentrations of natural radionuclides in the samples}

\subsubsection{Activity concentration in soil}

The activity concentrations of the radionuclides in the soil samples collected from the study area and control locations are presented in Table 2 and illustrated in Figure 3 respectively. All radionuclides detected and quantified came from the natural occurring $232 \mathrm{Th}$ and $238 \mathrm{U}$ decay series, as well as the non series $40 \mathrm{~K}$. The specific activity concentration of $40 \mathrm{~K}$ ranged from $92.85 \pm 29.06$ to $537.28 \pm 99.28 \mathrm{~Bq} \mathrm{~kg}-1$, with an average of $270.14 \pm 61.79 \mathrm{~Bq} \mathrm{~kg}-1$. The lowest and highest values were obtained in Soo1 and Soo7 locations respectively. Also, specific activity concentration of $232 \mathrm{Th}$ ranged from $6.28 \pm 2.15$ to $41.22 \pm 12.60 \mathrm{~Bq} \mathrm{~kg}-1$, with an average of $23.23 \pm 7.67 \mathrm{~Bq} \mathrm{~kg}-1$, the lowest and highest occurring in locations Soo4 and Soo2 respectively. Similarly, the specific activity concentration of $238 \mathrm{U}$ ranged from $7.28 \pm 2.10$ to $20.18 \pm 6.74 \mathrm{~Bq} \mathrm{~kg}-1$ with an average of $12.14 \pm 4.17 \mathrm{~Bq} \mathrm{~kg}-1$, the lowest and highest occurring in locations Soo5 and Soo1 respectively. In the control area, the specific activity concentration of $40 \mathrm{~K}$ ranging from $193.86 \pm 41.78$ to $264.65 \pm 51.02 \mathrm{~Bq} \mathrm{~kg}-1$ with an average of $220.14 \pm 42.37 \mathrm{~Bq} \mathrm{~kg}-1$, with the lowest and highest values in locations Soo13 and Soo12 respectively. Also, 
specific activity concentration of $232 \mathrm{Th}$ ranged from $18.16 \pm 4.58$ to $20.31 \pm 4.11 \mathrm{~Bq} \mathrm{~kg}-1$, with an average of $19.13 \pm 5.30 \mathrm{~Bq} \mathrm{~kg}-1$, with the lowest and highest occurring in Soo11 and Soo13 locations respectively. Similarly, the specific activity concentration of $238 \mathrm{U}$ ranged from $5.98 \pm 1.47$ to $11.82 \pm 2.11 \mathrm{~Bq} \mathrm{~kg}-1$ with an average of $8.64 \pm 2.46 \mathrm{~Bq} \mathrm{~kg}-1$, with the lowest and highest occurring in Soo13 and Soo11 locations respectively. The mean concentrations of $40 \mathrm{~K}, 232 \mathrm{Th}$ and $238 \mathrm{U}$ in the study area are; $270.14 \pm 61.79,23.23 \pm 7.67$ and $12.14 \pm 4.17 \mathrm{~Bq} \mathrm{~kg}-1$ while in control area they are; $220.35 \pm 42.37,19.38 \pm 5.30$ and $8.64 \pm 2.46 \mathrm{~Bq} \mathrm{~kg}-1$ respectively. The mean values for the radionuclides concentration in all the samples analyzed were below the International standard limits of 424, 20.5 and 20 Bq kg-1 which have a confidence interval that lies between 417 - 432, 19.2 - 21.9 and 18 22 for $40 \mathrm{~K}, 232 \mathrm{Th}$ and $238 \mathrm{U}$ respectively except 232Th (IAEA, 2000). In some locations, the radionuclides concentrations of $232 \mathrm{Th}$ were higher than the International standard limits. This may be as a result of radon gas $(220 \mathrm{Rn})$ from the $232 \mathrm{Th}$ series originating from the air which might have been deposited on the soil. This thereby increases 232Th concentration (Fasasi et al., 2003; Orosun et al., 2016a). Likewise, the activity concentration of $40 \mathrm{~K}, 232 \mathrm{Th}$ and $238 \mathrm{U}$, are averagely lower in Opa environment, this could be as a result of no industrial activity in that environment.

Table 2 Activity concentration of radionuclides in soil samples

\begin{tabular}{|c|c|c|c|c|}
\hline \multirow[t]{2}{*}{$\mathrm{S} / \mathrm{N}$} & \multirow[t]{2}{*}{ Samples name } & \multicolumn{3}{|c|}{ Radioactivity content $\left(\mathrm{Bq} \mathrm{kg}^{-1}\right)$} \\
\hline & & ${ }^{40} \mathrm{~K}$ & ${ }^{232} \mathrm{Th}$ & ${ }^{238} \mathrm{U}$ \\
\hline & & \multicolumn{3}{|c|}{ Study area } \\
\hline 1 & Soo1 & $92.85 \pm 29.06$ & $32.01 \pm 11.07$ & $20.18 \pm 6.74$ \\
\hline 2 & Soo2 & $352.62 \pm 88.34$ & $41.22 \pm 12.6$ & $14.62 \pm 5.10$ \\
\hline 3 & Soo3 & $186.62 \pm 40.93$ & $19.73 \pm 6.47$ & $10.22 \pm 3.70$ \\
\hline 4 & Soo4 & $201.60 \pm 51.11$ & $6.28 \pm 2.15$ & $12.10 \pm 4.36$ \\
\hline 5 & Soo5 & $429.07 \pm 84.63$ & $20.33 \pm 5.84$ & $7.28 \pm 2.10$ \\
\hline 6 & Soo6 & $142.62 \pm 30.98$ & $21.76 \pm 5.46$ & $9.07 \pm 2.53$ \\
\hline 7 & Soo7 & $537.28 \pm 99.28$ & $33.26 \pm 9.53$ & $8.10 \pm 1.84$ \\
\hline 8 & Soo8 & $253.63 \pm 46.47$ & $16.56 \pm 4.89$ & $13.52 \pm 3.54$ \\
\hline 9 & Soo9 & $342.84 \pm 61.73$ & $20.02 \pm 5.63$ & $17.11 \pm 6.03$ \\
\hline \multirow[t]{3}{*}{10} & Soo10 & $162.30 \pm 35.92$ & $21.15 \pm 7.06$ & $9.19 \pm 2.55$ \\
\hline & Mean & $270.14 \pm 61.79$ & $23.23 \pm 7.67$ & $12.14 \pm 4.17$ \\
\hline & & \multicolumn{3}{|c|}{ Control area } \\
\hline 11 & Soo11 & $202.53 \pm 32.22$ & $18.16 \pm 4.58$ & $11.82 \pm 3.11$ \\
\hline 12 & Soo12 & $264.65 \pm 51.02$ & $19.67 \pm 6.81$ & $8.11 \pm 2.51$ \\
\hline \multirow[t]{2}{*}{13} & Soo13 & $193.86 \pm 41.78$ & $20.31 \pm 4.11$ & $5.98 \pm 1.47$ \\
\hline & Mean & $220.35 \pm 42.37$ & $19.38 \pm 5.30$ & $8.64 \pm 2.46$ \\
\hline
\end{tabular}




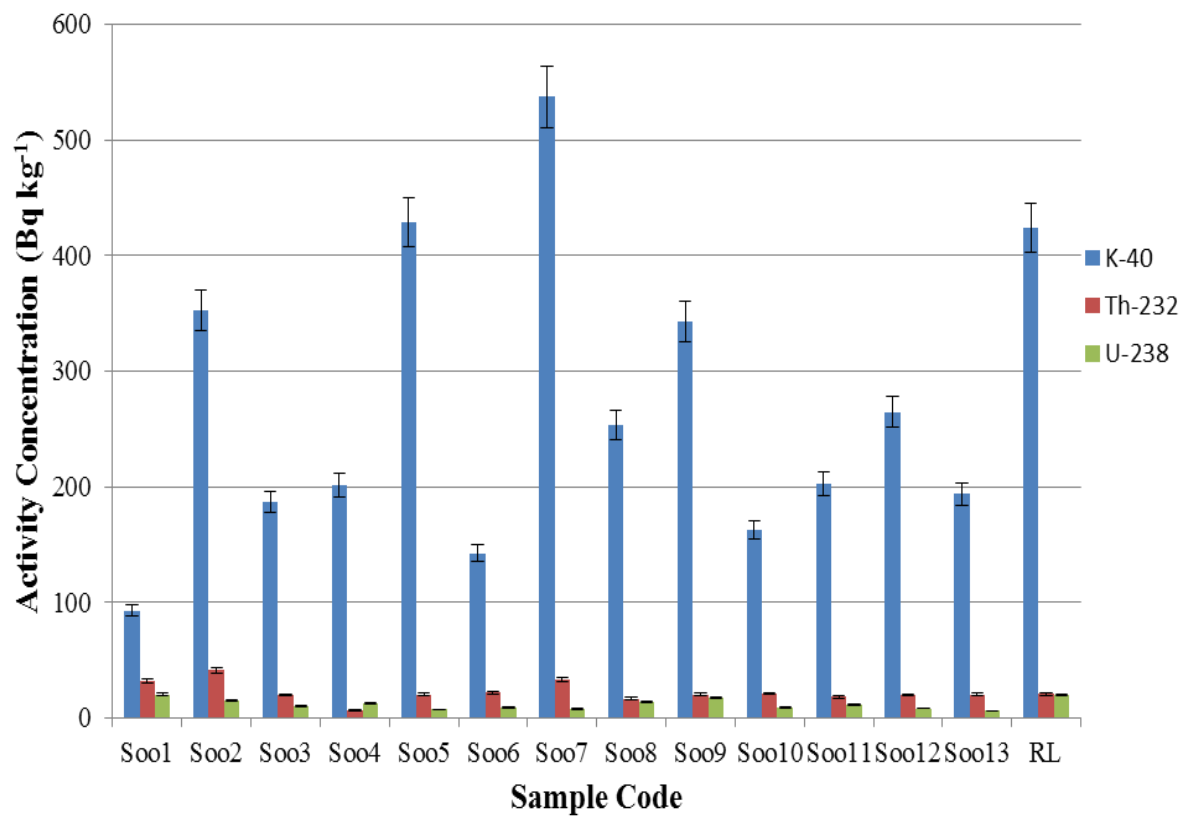

Fig. 3 Activity Concentration in Soil Samples. Key: RL: Recommended limit by IAEA (2000).

\subsubsection{Activity concentration in food samples}

The activity concentrations of the radionuclides in the food samples collected from the study area and control locations are presented in Table 3 and illustrated in Figure 4 respectively. All radionuclides detected and quantified are from the natural occurring $232 \mathrm{Th}$ and $238 \mathrm{U}$ decay series, as well as the non series $40 \mathrm{~K}$. For the study area, the specific activity concentration of $40 \mathrm{~K}$ ranged from $53.27 \pm 11.96$ to $124.9 \pm 29.13 \mathrm{~Bq} \mathrm{~kg}-1$ with an average of $89.41 \pm 24.15 \mathrm{~Bq} \mathrm{~kg}-1$, the lowest and highest values occurring in jute leaves 1 (Corchorus) and jute leaves 2 (Corchorus) at locations 7 and 8 respectively. Also, the specific activity concentration of $232 \mathrm{Th}$ ranged from $5.12 \pm 1.15$ to $21.15 \pm 7.11 \mathrm{~Bq} \mathrm{~kg}-1$ with an average of $13.17 \pm 4.48 \mathrm{~Bq} \mathrm{~kg}-1$, with the lowest and highest occurring in processed cassava to garri (Manihot esculentun) and jute leaves 2 (Corchorus) in the locations 10 and 8 respectively. Similarly, the specific activity concentration of $238 \mathrm{U}$ ranged from $5.27 \pm 1.70$ to $13.13 \pm 4.74 \mathrm{~Bq} \mathrm{~kg}-1$ with an average of $8.56 \pm 2.80 \mathrm{~Bq} \mathrm{~kg}-1$, with the lowest and highest occurring in dried yellow maize (Zea mays) and jute leaves 1 (Corchorus) in the locations 9 and 7 respectively. For the control area, in the same Table 3, the specific activity concentration of $40 \mathrm{~K}$ ranging from $46.58 \pm 9.38$ to $64.34 \pm 20.43 \mathrm{~Bq}$ $\mathrm{kg}-1$ with an average of $54.36 \pm 16.69 \mathrm{~Bq} \mathrm{~kg}-1$, with the lowest and highest values occurring in water leaves (Talinum triangulae) and jute leaves (Corchorus) locations 21 and 20 respectively. Also, the specific activity concentration of $232 \mathrm{Th}$, ranged from $3.35 \pm 2.02$ to $9.37 \pm 3.26 \mathrm{~Bq} \mathrm{~kg}-1$, with an average of $6.56 \pm 2.52 \mathrm{~Bq} \mathrm{~kg}-1$, with lowest and highest occurring in jute leaves (Corchorus) and water leaves (Talinum triangulae) locations 20 and 21 respectively. Similarly, the specific activity concentration of $238 \mathrm{U}$ ranged from 0 to $10.27 \pm 4.26 \mathrm{~Bq} \mathrm{~kg}-1$ with an average of $8.01 \pm 3.45 \mathrm{~Bq} \mathrm{~kg}-1$, with the lowest and highest 
occurring in jute leaves (Corchorus) and water leaves (Talinum triangulae) locations 20 and 21 respectively. The mean concentrations of $40 \mathrm{~K}, 232 \mathrm{Th}$ and $238 \mathrm{U}$ in the study area are; $89.41 \pm 24.15,13.17 \pm 4.48$ and $8.56 \pm 2.80 \mathrm{~Bq} \mathrm{~kg}-1$ respectively while in the control area they are; $54.36 \pm 16.69,6.56 \pm 2.52$ and $8.01 \pm 3.45 \mathrm{~Bq} \mathrm{~kg}-1$ respectively. The mean activity concentration of $40 \mathrm{~K}, 232 \mathrm{Th}$ and $238 \mathrm{U}$, are averagely lower in Opa (the control area) environment in comparison with the study area. This could be as a result of no industrial activities in Opa. In this study, it is also noted that the leafy vegetables seem to absorb more radionuclides than other food crops such as maize and roots food product. Potassium recorded the highest overall mean in all the food composites. However, $40 \mathrm{~K}$ is an essential biological element and its concentration in human tissue is under close metabolic (homeostatic) control (UNSCEAR, 1982). Variation of 40K concentration in dietary composition do not influence significantly the radiation dose received (Makon et al., 2011). The result of this study is in comparison with the values recorded for activity concentration of radionuclides in vegetables, grains and tubers collected in oil and gas areas in the Niger Delta region in Nigeria as reported by Avwiri et al., (2013) and Tchokossa et al., (2013).

Table 3 Activity concentration of radionuclides in food samples

\begin{tabular}{|c|c|c|c|c|c|c|}
\hline \multirow[b]{2}{*}{$\mathrm{S} / \mathrm{N}$} & \multicolumn{3}{|c|}{ Sample Names } & \multicolumn{3}{|c|}{ Radioactivity content $\left(\mathrm{Bq} \mathrm{kg}^{-1}\right)$} \\
\hline & $\begin{array}{l}\text { Sample } \\
\text { code }\end{array}$ & $\begin{array}{l}\text { English } \\
\text { names }\end{array}$ & $\begin{array}{l}\text { Botanical } \\
\text { names }\end{array}$ & ${ }^{40} \mathrm{~K}$ & ${ }^{232} \mathrm{Th}$ & ${ }^{238} \mathrm{U}$ \\
\hline & & & & \multicolumn{3}{|c|}{ Study area } \\
\hline 1 & VSo1 & Water Leaves@ Fashina 1 & $\begin{array}{l}\text { Talinum } \\
\text { triangulae }\end{array}$ & $60.12 \pm 21.72$ & $9.82 \pm 3.15$ & $9.77 \pm 2.83$ \\
\hline 2 & VSo2 & Water Leaves@ Fashina 2 & $\begin{array}{l}\text { Talinum } \\
\text { triangulae }\end{array}$ & $121.53 \pm 30.66$ & $16.72 \pm 4.63$ & $6.75 \pm 2.66$ \\
\hline 3 & VSo3 & Cassava @ Fashina 1 & $\begin{array}{l}\text { Manihot } \\
\text { esculentun }\end{array}$ & $78.39 \pm 26.73$ & $17.53 \pm 5.62$ & $7.22 \pm 1.98$ \\
\hline 4 & VSo4 & Cassava@ Fashina 2 & $\begin{array}{l}\text { Manihot } \\
\text { esculentun }\end{array}$ & $98.66 \pm 17.23$ & $13.17 \pm 3.84$ & $8.00 \pm 2.17$ \\
\hline 5 & VSo5 & $\begin{array}{c}\text { Cassava Processed garri @ } \\
\text { Fashina }\end{array}$ & $\begin{array}{l}\text { Manihot } \\
\text { esculentun }\end{array}$ & $88.45 \pm 12.98$ & $5.12 \pm 1.15$ & $10.45 \pm 3.77$ \\
\hline 6 & VSo6 & $\begin{array}{c}\text { Jute Leaves@ @ Fashina } 1 \\
\text { (Ewedu) }\end{array}$ & Corchorus & $53.27 \pm 11.96$ & $8.16 \pm 2.07$ & $13.13 \pm 4.74$ \\
\hline 7 & VSo7 & $\begin{array}{c}\text { Jute Leaves @ Fashina } 2 \\
\text { (Ewedu) }\end{array}$ & Corchorus & $124.9 \pm 29.13$ & $21.15 \pm 7.11$ & $11.44 \pm 2.88$ \\
\hline 8 & VSo8 & $\begin{array}{l}\text { African Spinach @ } \\
\text { Fashina } 1 \text { (Efotete) }\end{array}$ & $\begin{array}{l}\text { Amaranthus } \\
\text { hybridus }\end{array}$ & $69.93 \pm 20.18$ & $14.76 \pm 5.24$ & $5.74 \pm 1.03$ \\
\hline 9 & VSo9 & $\begin{array}{c}\text { African Spinach @ Fashina } \\
2 \text { (Efotete) }\end{array}$ & $\begin{array}{l}\text { Amaranthus } \\
\text { hybridus }\end{array}$ & $111.55 \pm 39.31$ & $16.28 \pm 6.01$ & $7.86 \pm 2.41$ \\
\hline \multirow[t]{3}{*}{10} & VSo10 & $\begin{array}{c}\text { Dried Yellow Maize @ } \\
\text { Fashina }\end{array}$ & Zea mays & $87.25 \pm 17.25$ & $8.99 \pm 1.88$ & $5.27 \pm 1.70$ \\
\hline & & Mean & & $89.41 \pm 24.15$ & $13.17 \pm 4.48$ & $8.56 \pm 2.80$ \\
\hline & & & & \multicolumn{3}{|c|}{ Control area } \\
\hline 11 & VSo11 & Water Leaves @ Opa & $\begin{array}{l}\text { Talinum } \\
\text { triangulae }\end{array}$ & $46.58 \pm 9.38$ & $9.37 \pm 3.26$ & $10.27 \pm 4.26$ \\
\hline 12 & VSo12 & Dried White Maize @ Opa & Zea & $.17 \pm 1$ & $6.02 \pm 2$ & $9.42 \pm 4.18$ \\
\hline 13 & VSo13 & Jute Leaves @ Opa & Corchorus & $64.34 \pm 20.43$ & $3.35 \pm 2.02$ & \\
\hline & & Mean & & $54.36 \pm 16.69$ & $6.56 \pm 2.53$ & $8.01 \pm 2.45$ \\
\hline
\end{tabular}




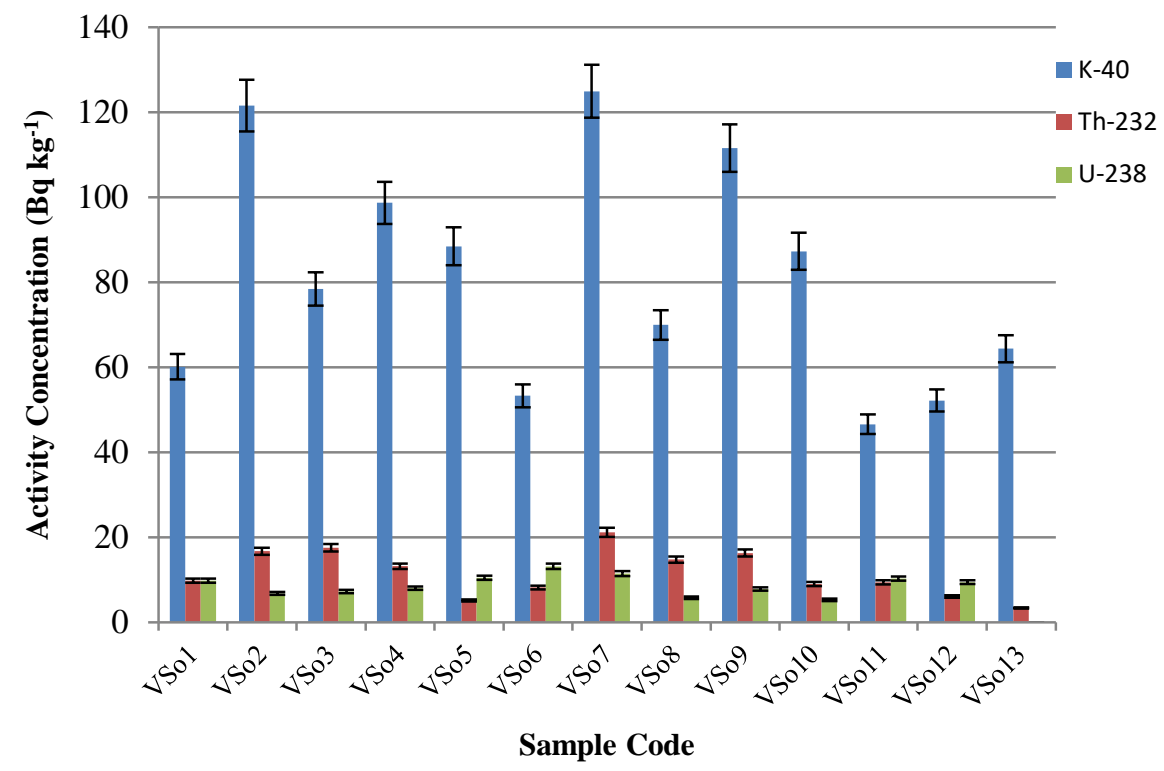

Fig. 4 Activity Concentration in Food Samples

\subsubsection{Activity concentration in water samples}

The activity concentrations of the radionuclides in the water samples collected from the study and control locations are presented in Table 4 and illustrated in Figure 5. All the radionuclides detected and quantified came from the natural occurring $232 \mathrm{Th}$ and $238 \mathrm{U}$ decay series, as well as the non series $40 \mathrm{~K}$. Generally, the radionuclides concentrations in water samples were a function of geological formation of the area (Strain and Watson, 1979). The specific activity concentration ranged from $65.38 \pm 15.67$ to $98.62 \pm 20.92 \mathrm{~Bq}$ L-1 with an average of $82.00 \pm 18.48 \mathrm{~Bq} \mathrm{~L}-1$ for $40 \mathrm{~K}, 4.41 \pm 1.34$ to $8.12 \pm 1.34 \mathrm{~Bq} \mathrm{~L}-1$ with an average of $6.27 \pm 1.84 \mathrm{~Bq} \mathrm{~L}-1$ for $232 \mathrm{Th}$ and $4.15 \pm 2.11$ to $6.21 \pm 2.34 \mathrm{~Bq} \mathrm{~L}-1$ with an average of $5.18 \pm 2.23 \mathrm{~Bq} \mathrm{~L}-1$ for $238 \mathrm{U}$ in borehole water. Also it ranged from $46.09 \pm 11.28$ to $62.91 \pm 19.62 \mathrm{~Bq} \mathrm{~L}-1$ with an average of $54.50 \pm 16.00 \mathrm{~Bq} \mathrm{~L}-1$ for $40 \mathrm{~K}$, $9.73 \pm 4.02$ to $10.11 \pm 3.16 \mathrm{~Bq} \mathrm{~L}-1$ with an average of $9.92 \pm 3.62 \mathrm{~Bq} \mathrm{~L}-1$ for $232 \mathrm{Th}$ and from $7.12 \pm 3.11$ to $8.14 \pm 2.21 \mathrm{~Bq} \mathrm{~L}-1$ with an average of $7.63 \pm 2.70 \mathrm{~Bq} \mathrm{~L}-1$ for $238 \mathrm{U}$ in stream water. While in well water, it ranged from $53.82 \pm 13.27$ to $96.58 \pm 20.01 \mathrm{~Bq} \mathrm{~L}$ 1 with an average of $75.2 \pm 18.90 \mathrm{~Bq} \mathrm{~L}-1$ for $40 \mathrm{~K}$, from $7.78 \pm 3.17$ to $13.02 \pm 2.92 \mathrm{~Bq}$ $\mathrm{L}-1$ with an average of $10.4 \pm 3.05 \mathrm{~Bq} \mathrm{~L}-1$ for $232 \mathrm{Th}$ and from $5.38 \pm 2.27$ to $11.02 \pm$ $4.21 \mathrm{~Bq} \mathrm{~L}-1$ with an average of $8.20 \pm 3.38 \mathrm{~Bq} \mathrm{~L}-1$ for $238 \mathrm{U}$. As for rain water when the factory is not working, the specific activity concentration ranges from $47.08 \pm 12.58$ to $77.38 \pm 9.51 \mathrm{~Bq} \mathrm{~L}-1$ with an average of $62.23 \pm 11.15 \mathrm{~Bq} \mathrm{~L}-1$ for $40 \mathrm{~K}$, from $8.16 \pm 3.01$ to $13.04 \pm 6.02 \mathrm{~Bq} \mathrm{~L}-1$ with an average of $10.60 \pm 4.76 \mathrm{~Bq} \mathrm{~L}-1$ for $232 \mathrm{Th}$ and from 5.28 \pm 2.10 to $8.06 \pm 3.12 \mathrm{~Bq} \mathrm{~L}-1$ with an average of $6.67 \pm 2.66 \mathrm{~Bq} \mathrm{~L}-1$ for $238 \mathrm{U}$, while for rain water during the factory working period, it ranged from $55.67 \pm 14.34$ to $86.89 \pm$ $11.28 \mathrm{~Bq} \mathrm{~L}-1$ with an average of $71.28 \pm 12.90 \mathrm{~Bq} \mathrm{~L}-1$ for $40 \mathrm{~K}, 9.99 \pm 5.01$ to $16.05 \pm$ $2.19 \mathrm{~Bq} \mathrm{~L}-1$ with an average of $13.02 \pm 3.87 \mathrm{~Bq} \mathrm{~L}-1$ for $232 \mathrm{Th}$ and from $9.03 \pm 4.10$ to 
$12.01 \pm 3.41 \mathrm{~Bq} \mathrm{~L}-1$ with an average of $10.52 \pm 3.77 \mathrm{~Bq} \mathrm{~L}-1$ for $238 \mathrm{U}$. For the control area in the same table, the specific activity of $40 \mathrm{~K}$ was $69.83 \pm 20.14,11.74 \pm 4.18$ for $232 \mathrm{Th}$ and $11.53 \pm 3.87$ for $238 \mathrm{U}$ in well water, while in borehole water the activity concentration was $61.96 \pm 16.20$ for $40 \mathrm{~K}, 9.89 \pm 2.26$ for $232 \mathrm{Th}$ and $7.36 \pm 3.08$ for 238 U. From this study, the largest contribution to the overall mean activity in all the various types of water sample came mainly from $40 \mathrm{~K}$ with the average of $69.04 \pm 15.49$ $\mathrm{Bq}$ L-1 when compared with that $232 \mathrm{Th}$ and $238 \mathrm{U}$ with the average values of $10.04 \pm$ 3.43 and $7.64 \pm 2.95 \mathrm{~Bq} \mathrm{~L}-1$ respectively. The overall mean radionuclides concentration of $238 \mathrm{U}$ was lower than the world average value of $10 \mathrm{~Bq} \mathrm{~L}-1$, for $232 \mathrm{Th}$ was higher than the world average value of $1 \mathrm{~Bq} \mathrm{~L}-1$ while for $40 \mathrm{~K}$ no limit is needed as potassium content of the body is under homeostatic control and is not influenced by environmental levels (UNSCEAR, 2000; CNSC, 2011; WHO, 2011 and Orosun et al., 2018). The activity concentration of $40 \mathrm{~K}, 232 \mathrm{Th}$ and $238 \mathrm{U}$ are averagely lower in Opa environment in comparison with the study area. This could be as a result of lack of industrial activities in the environment. Generally, the concentrations of $232 \mathrm{Th}$ and $238 \mathrm{U}$ for rain water during the factory working period at the study were higher than other sources of water in the area. This may be as a result of radon gases (222Rn and $220 \mathrm{Rn})$ originating from the air as a result of the iron smelting. Opa environment consist a series of bedrock ridges which may contribute to the activity concentrations in water samples gotten in the area.

Table 4 Activity Concentration of Radionuclides in Water Samples

\begin{tabular}{|c|c|c|c|c|}
\hline \multirow[b]{2}{*}{$\mathrm{S} / \mathrm{N}$} & \multirow[b]{2}{*}{ Sample Names } & \multicolumn{3}{|c|}{ Radioactivity content $\left(\mathrm{Bq} \mathrm{L}^{-1}\right)$} \\
\hline & & ${ }^{40} \mathrm{~K}$ & ${ }^{232} \mathrm{Th}$ & ${ }^{238} \mathrm{U}$ \\
\hline & & \multicolumn{3}{|c|}{ Study area } \\
\hline 1 & WSO1 & $65.38 \pm 15.67$ & $4.41 \pm 1.34$ & $4.15 \pm 2.11$ \\
\hline \multirow[t]{2}{*}{2} & WSO2 & $98.62 \pm 20.92$ & $8.12 \pm 2.23$ & $6.21 \pm 2.34$ \\
\hline & Mean & $82.00 \pm 18.30$ & $6.27 \pm 1.79$ & $5.18 \pm 2.23$ \\
\hline 3 & WSO3 & $46.09 \pm 11.28$ & $10.11 \pm 3.16$ & $8.14 \pm 2.21$ \\
\hline \multirow[t]{2}{*}{4} & WSO4 & $62.91 \pm 19.62$ & $9.73 \pm 4.02$ & $7.12 \pm 3.11$ \\
\hline & Mean & $54.50 \pm 15.45$ & $9.92 \pm 3.59$ & $7.63 \pm 2.66$ \\
\hline 5 & WSO5 & $96.58 \pm 20.01$ & $13.02 \pm 2.92$ & $11.02 \pm 4.21$ \\
\hline \multirow[t]{2}{*}{6} & WSO6 & $53.82 \pm 13.27$ & $7.78 \pm 3.17$ & $5.38 \pm 2.27$ \\
\hline & Mean & $75.20 \pm 16.64$ & $10.4 \pm 3.05$ & $8.20 \pm 3.24$ \\
\hline 7 & WSO7 & $77.38 \pm 9.15$ & $13.04 \pm 6.02$ & $8.06 \pm 3.12$ \\
\hline \multirow[t]{2}{*}{8} & WSO8 & $47.08 \pm 12.58$ & $8.16 \pm 3.01$ & $5.28 \pm 2.10$ \\
\hline & Mean & $62.23 \pm 11.05$ & $10.60 \pm 4.52$ & $6.67 \pm 2.61$ \\
\hline 9 & WSO9 & $55.67 \pm 14.34$ & $16.05 \pm 2.19$ & $12.01 \pm 3.41$ \\
\hline \multirow[t]{4}{*}{10} & WSO10 & $86.89 \pm 11.28$ & $9.99 \pm 5.01$ & $9.03 \pm 4.10$ \\
\hline & Mean & $71.28 \pm 12.81$ & $13.02 \pm 3.60$ & $10.52 \pm 3.76$ \\
\hline & Overall mean & $69.04 \pm 15.29$ & $10.04 \pm 3.31$ & $7.64 \pm 2.90$ \\
\hline & & \multicolumn{3}{|c|}{ Control area } \\
\hline 11 & WSO11 & $69.83 \pm 20.14$ & $11.74 \pm 4.18$ & $11.53 \pm 3.87$ \\
\hline \multirow[t]{2}{*}{12} & WSO12 & $61.96 \pm 16.20$ & $9.89 \pm 2.26$ & $7.36 \pm 3.08$ \\
\hline & Mean & $65.90 \pm 18.17$ & $10.82 \pm 3.22$ & $9.45 \pm 3.48$ \\
\hline
\end{tabular}




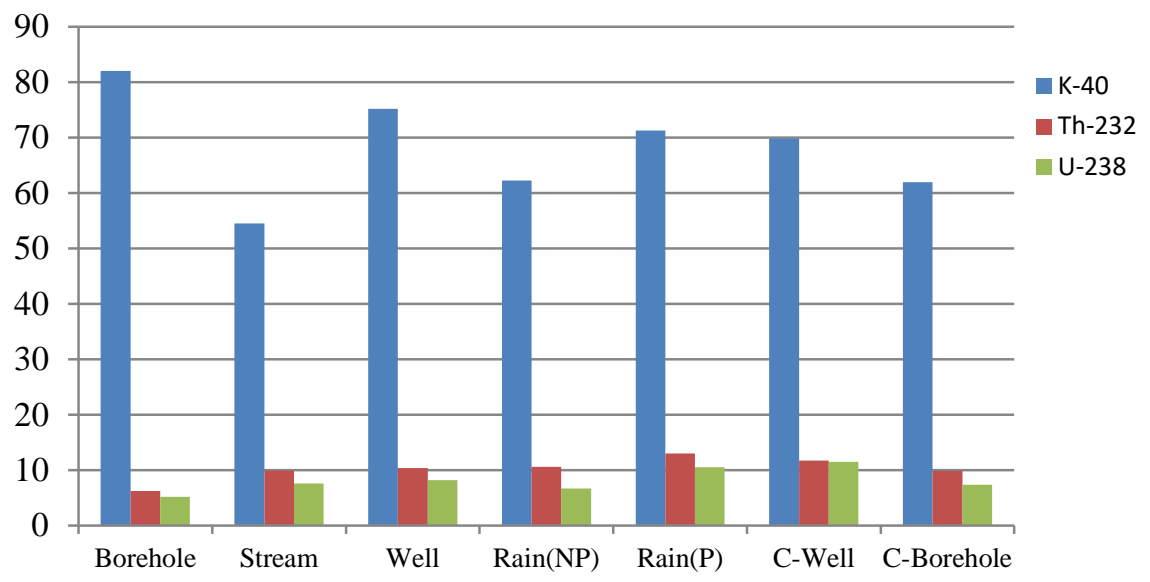

Fig. 5 Activity Concentration in Water Samples

\subsection{Transfer factor of the radionuclides}

The transfer factors (TF) from soil to food samples in the study and control areas for $238 \mathrm{U}, 232 \mathrm{Th}$ and $40 \mathrm{~K}$ were obtained using equation 2.3 and presented in Table 5. The $\mathrm{TF}$ from soil to plant at the study area ranged from 0.20 to 0.57 with an average of 0.39 for $40 \mathrm{~K}$, the highest was recorded in Corchorus and the lowest in Zea mays at location points 7 and 9 respectively. Also, it ranged from 0.26 to 0.84 with an average of 0.61 for $232 \mathrm{Th}$, the highest was in Talinum triangulae and lowest in Corchorus at location points 5 and 7 respectively. For the $238 \mathrm{U}$, it ranged from 0.40 to 0.97 with an average of 0.73 , the highest in Amaranthus hybridus and lowest in Talinum triangulae at location points 4 and 5 respectively.

At the control site, the TFs for $40 \mathrm{~K}$ it ranged between 0.18 to 0.33 with an average of 0.26 , the highest in Corchorus and lowest in Talinum triangulae at location points 20 and 21 respectively, while for $232 \mathrm{Th}$ it between 0.17 to 0.51 with an average of 0.33 with the highest in Talinum triangulae and lowest in Corchorus at location points 21 and 20 respectively. The TF for $238 \mathrm{U}$ were computed for two of the samples (Talinum triangulae and Zea mays) at location points 21 and 19 respectively whose values ranged between 0.80 and 1.27, with average of 1.03. The TF for the other one sample (Corchoru)s at point 20 was not computed because the activity concentration was below detection. This may be as a result of their lower radionuclides absorption from the soil to plant.

It was noted that at study area the mean TFs were very high in comparison with the control area for all the radionuclides, this may due to industrial activities which result in high absorption of radionuclides from the soil and deposit on plants present in such environment. The overalls mean were in the order of $238 \mathrm{U}>232 \mathrm{Th}>40 \mathrm{~K}$ respectively. Care must be taken in some areas where TFs are high as the consumption of such crops or plants have serious health implications, though, the overall assessment of the naturally occurring radionuclides in the soil of the study area does not give a cause for alarm at this stage. 
Table 5 Transfer factor soil-food of the radionuclides

\begin{tabular}{|c|c|c|c|c|}
\hline \multirow[t]{2}{*}{$\mathrm{S} / \mathrm{N}$} & \multirow[t]{2}{*}{ Transfer Code } & \multicolumn{3}{|c|}{ Transfer Factor } \\
\hline & & ${ }^{40} \mathrm{~K}$ & ${ }^{232} \mathrm{Th}$ & ${ }^{238} \mathrm{U}$ \\
\hline & & \multicolumn{3}{|c|}{ Study area } \\
\hline 1 & Vso1/Soo1 & 0.24 & 0.59 & 0.72 \\
\hline 2 & Vso2/Soo2 & 0.36 & 0.84 & 0.40 \\
\hline 3 & Vso3/Soo3 & 0.48 & 0.83 & 0.79 \\
\hline 4 & Vso4/Soo4 & 0.53 & 0.67 & 0.78 \\
\hline 5 & Vso5/Soo5 & 0.44 & 0.82 & 0.86 \\
\hline 6 & Vso6/Soo6 & 0.57 & 0.26 & 0.65 \\
\hline 7 & Vso7/Soo7 & 0.35 & 0.51 & 0.78 \\
\hline 8 & Vso8/Soo8 & 0.49 & 0.68 & 0.63 \\
\hline 9 & Vso9/Soo9 & 0.21 & 0.49 & 0.97 \\
\hline \multirow[t]{3}{*}{10} & Vso10/Soo10 & 0.20 & 0.44 & 0.72 \\
\hline & Mean & 0.39 & 0.61 & 0.73 \\
\hline & & \multicolumn{3}{|c|}{ Control area } \\
\hline 11 & Vso11/Soo11 & 0.18 & 0.48 & 1.27 \\
\hline 12 & Vso12/Soo12 & 0.26 & 0.33 & 0.80 \\
\hline \multirow[t]{2}{*}{13} & Vso13/Soo13 & 0.33 & 0.17 & BDL \\
\hline & Mean & 0.26 & 0.32 & $\mathrm{VCN}$ \\
\hline
\end{tabular}

\section{CONCLUSION AND RECOMMENDATIONS}

The radionuclides detected in the gamma spectrometry analysis belonged to the naturally-occurring series-decay $238 \mathrm{U}$ and $232 \mathrm{Th}$ as well as the non-series $40 \mathrm{~K}$. 238U and 232Th concentrations in some food and water samples were found to be higher than the recommended limit in the study area. The control area showed a trend of low activity concentrations in all the samples analyzed when compared to the study area. This can be attributed to the industrial activities in the study area. In addition, the transfer factor from soil to plant was found to be higher in $238 \mathrm{U}$ and $232 \mathrm{Th}$ compare to $40 \mathrm{~K}$. This might be attributed to the deposition of airborne radioactive particles of $238 \mathrm{U}$ and $232 \mathrm{Th}$ series on the surface of plants in the study area.

It is therefore recommended that further research work on the natural occurring radionuclides inside the factory should be done to know the occupational exposure rate of workers.

Acknowledgement: This paper is a part of the research done for environmental monitoring of residents in Fasina village, Ile-Ife, Osun State, Nigeria due to the iron smelting industry located in the area. The authors would like to thank the entire staff of Center for Energy Research and Development (CERD), Obafemi Awolowo University, Ile-Ife, Nigeria for giving their valuable time for the sample preparation and the gamma analysis of the samples. 


\section{REFERENCES}

1. Ali, A. A., Hussain, H. A. and Lubna, A. A. (2013): "Determination of Natural Radiation Contamination for Some Types of Legumes Available in the Iraqi Market". Advance Applied Science Research, 4 (5): $246-250$.

2. Amin, R. M and Ahmed, F. (2013): "Estimation of Annual Effective Dose to the Adult Egyptian Population Due to Natural Radioactivity Elements in Ingestion of Spices". Advance Applied Science Research, 4 (5): 350 - 354

3. Avwiri, G. O. and Alao, A. A. (2013): "Natural Radioactivity and Associated Radiation Hazards in Some Consumed Tubers and Cereals in Oil Mining Lease (OML) 58 and 61, Oil and Gas Producing Area, Niger Delta Region of Nigeria”. International Journal of Science and Research, 2 (1): 468 - 473.

4. Beretka, J. and Mathew, P. J. (1985): "Natural radioactivity of Australian Buildings, Materials, Industrial Wastes and By-Products". Health Physics, 48, 87-95.

5. CNSC (2011): "Canadian Guidelines for The Management Of Naturally Occurring

6. Radioactive Materials (Norm)", Canadian Nuclear Safety Commission, Canada. pp 25.

7. Environmental Protection Agency (EPA, 2015): "Radioactive Source Reduction \& Management". Poster: Radioactive Scrap - Be Aware! (NUREG/BR-0108, Revision 1). http://www.epa.gov/radiation/ understand/pathways.html.

8. Fasasi, M. K., Oyawale, A.A., Mokobia, C. E, Tchokossa, P, Ajayi, T.R., Balogun, F. A. (2003): "Natural radioactivity of the tar-sand deposits of Ondo State, Southwestern,

9. Nigeria". Nuclear Instruments and Methods in Physics Research A 505, 449-453.

10. Fitzgerald, J. J. (1969). "Applied Radiation and Control". Volume 1, Gondon and Breach Science Publication.

11. Food Balance Sheet (2014): "Open Data for Nigeria” African Development Bank Group.

12. Hall, E .J. R, (2000): "Radiobiology for the Radiologist" Printed by Lippincott Williams \& Wilkins 530 W7alnut Street Philadelphia, PA 19106 USA.

13. International Atomic Energy Agency, (IAEA) (1982): "Generic Models and Parameters for Assessing the Environmental Transfer of Radionuclides from Routine Releases". Safety Series 57, 61-65.

14. International Atomic Energy Agency, (IAEA) (1989): "Measurement of Radionuclide in Food and Environment". A Guidebook Technical Report, Series No 295, IAEA, Vienna.

15. International Atomic Energy Agency, (IAEA) 2000: "IAEA-375 Radionuclides and Trace Elements in Soil”. International Atomic Energy Agency Analytical Control Services, Vienna, Austria.

16. International Atomic Energy Agency, (IAEA) (2004): "Code of Conduct on the Safety and Security of Radioactive Sources". IAEA, Vienna.

17. International Commission on Radiological Protection, (ICRP) (1994): "Dose Coefficient for Intakes of Radionuclides by Worker". Publication No: 68 Pergamon Press, Oxford. 1994.

18. Larmash, J.R. (1983): "Introduction to Nuclear Engineering". Adison-Wesley Publ. Company.

19. Makon, T. B., Nemba, R. M, Tchokossa, P. (2011): "Investigation of Gamma-Emitting Natural Radioactive Contents in Three Types of Vernonia Consumed in Cameron". World of Journal Nuclear Science Technology, Vol. 1 37-45.

20. Owoade, K. O., Hopke, P. K., Olise, F. S., Ogundele, L. T., Fawole, O G., Olaniyi, B. H., Jegede, O. O., Ayoola, M. A., Bashiru, M. I. (2015): "Chemical Compositions and Source Identification of Particulate Matter (PM2.5 and PM2.5-10) from a Scrap Iron and Steel Smelting Industry along the Ife-Ibadan highway". Nigeria Atmospheric Pollution Research 6 (2015) 107-119.

21. Orosun. M. M, Alabi A. B, Olawepo .A. O, Orosun. R. O., Lawal T. O. and Ige. S. O (2018). Radiological Safety of Water from Hadejia River. IOP Conf. Series: Earth and Environmental Science 173 (2018) 012036 doi:10.1088/1755-1315/173/1/012036

22. Orosun, M. M., Lawal, T. O., \& Akinyose, F. C. (2016a). Natural radionuclide concentrations and radiological impact assessment of soil and water in Tanke-Ilorin, Nigeria. Zimbabwe Journal of Science \& Technology, 11, 158-172.

23. Orosun. M. M., Tchokossa P., Lawal T. O., Bello S. O., Ige S. O. and Nwankwo L. I. (2016b): “Assessment of heavy metal pollution in drinking water due to mining and smelting activities in Ajaokuta", Nigerian Journal of Technological Development, Vol. 13; 30-38. doi: http://dx.doi.org/10.4314/njtd.v13i1.6

24. Petrucci, R. H., Harwood, W. S., and Herring, F. G. (2002): "General Chemistry". Prentice-Hall 8th ed., pp 1025-26.

25. Tchokossa, P., Olomo, J.B., Balogun F.A. and Adesanmi C.A., (2013): "Assessment of Radioactivity Contents of Food in the Oil and Gas Producing Areas in Delta State, Nigeria". International Journal of Science and Technology (IJST).Volume 3 No.4, pp 245-250. ISSN 2224-3577. http://www.ejournalofsciences.org. 
26. Tufail, M., Nasim, A., Sabiba, J., Tehsin, H. (2007): "Natural Radioactivity Hazards of Building Blocks Fabricated from Soil Two Districts of Pakistan". Journal of Radiological Protection Vol. 27, pp. 481-492.

27. Strain, C. D and Watson, J. E, (1979): "An Evaluation of 226Rn and 222Rn Concentrations in Ground and Surface Water near a Phosphate Mining and Manufacturing Facilities". Health Physics, (37) 33-47.

28. United Nations Economic Commission for Europe, (UNECE) (2006): "Monitoring and response procedures for Radioactive Scrap Metal". New York and Geneva, United Nations. http://www.unece.org/trans/radiation/ 2ndMeeting.html.

29. United Nations Scientific Committee on the Effect of Atomic Radiation, (UNSCEAR) (2000): "Sources and Effects of Ionizing Radiation in Report to the General Assembly with Scientific Annexes" New York, United Nations.

30. United Nations Scientific Committee on the Effect of Atomic Radiation, (UNSCEAR) (1982): "Ionization Radiations: Sources and Biological Effects". United Nations, New York.

31. Veiga, R. G., Sanches, N., Anjos, R. M., Macario, K., Bastos, J., Iguatemy, M., Aguitar, J. G., Santos, M. A., Mosquera, B., Carvaiho, C., Baptista, M., Umisedo, N. K. (2006): "Measurement of Natural Radioactivity in Brazilian Beach Sands". Radiation Measurements 41: 189-196.

32. Velasco, H., Ayub, J.J., Belli, N. and Sansone, U. (2004): " Temporal Trends of 137Cs and 40K Activity Flux from Soil to Plant in Grassland Ecosystems" Journal of Environmental Radioactivity, 71: 225-241.

33. World Health Organization, (WHO) (2008): Guidelines for Drinking Water Quality in Cooperating First Addendum vol.1, Recommendations, third Edition. Radiological Aspect Geneva: WHO Geneva.

34. World Health Organization, (WHO) (2011): "Guidelines for Drinking Water Quality". Fourth Edition Incorporating the 1st and 2nd Agenda vol.1 Recommendations; WHO Geneva

\section{PROCENA NIVOA RADIOAKTIVNOSTI I TRANSFER FAKTOR PRIRODNIH RADIONUKLIDA U OKOLINI TOPIONICE GVOŽĐA I ČELIKA U NASELJU FAŠINA, ILE-IFE, DRŽAVA OSUN, NIGERIJA}

$U$ studiji je izvršena procena nivoa radioaktivnosti $i$ transfer faktor prirodnih radionuklida $u$ okolini topionice gvožđa i čelika koja se nalazi u mestu Fašina, Ile-Ife, država Osun, u Nigeriji. Cilj ovog rada je procena izloženosti $u$ ispitivanoj oblasti, određivanje prisutnih radionuklida $i$ koncentracija njihovih aktivnosti (238U and 232Th and 40K) u uzorcima, kao i procena transfera radionuklida iz zemljišta u hranu. Za in-situ ispitivanje korišćen je prenosni merač sa sistemom globalnog pozicioniranja (GPS), dok je za merenje radioaktivnosti uzoraka korišćen kalibrisani NaI(Tl) detektorski sistem.Za spektometrijsku analizu korišćeno je 38 uzoraka iz zemljišta, hrane $i$ vode iz ispitivanog području (Fašina) i iz kontrolnog područja (Opa) u državi Osun, Nigerija. Uzorci zemljišta i hrane su sušeni u pećnici, usitnjeni i prosejani dok su uzorci vode zakiseljeni sa $10 \mathrm{~mL}$ $11 \mathrm{M} \mathrm{HCl}$ po litru kako bi se sprečila adsorpcija radionuklida na zidu posude. Nakon toga, svi uzorci su hermetički zatvoreni $i$ čuvani najmanje 28 dana u nepropusnom radonskom cilindričnom kontejneru kako bi se uspostavila ravnoteža. Srednje stope izloženosti u ispitivanom području su iznosile $0.14 \mu \mathrm{Sv}$ hr-1 i $0.12 \mu \mathrm{Sv}$ hr-1 za kontrolnu sredinu.Srednji nivo radioaktivnosti za $238 \mathrm{U}$, 232Th i $40 \mathrm{~K}$ bio je $12.14 \pm 4.17 \mathrm{~Bq} \mathrm{~kg}-1,23.23 \pm 7.67 \mathrm{~Bq} \mathrm{~kg}-1$ i $270.14 \pm 61.79 \mathrm{~Bq} \mathrm{~kg}-1$ u uzorcima zemljišta respektivno, i 8,56 $\pm 2,80 \mathrm{Bk} \mathrm{kg}-1,13,17 \pm 4.48 \mathrm{Bk} \mathrm{kg}-1$ i $89.41 \pm 24.15 \mathrm{Bk} \mathrm{kg-1} \mathrm{u} \mathrm{uzorcima}$ hrane respektivno. Slično tome, u uzorcima vode vrednosti su iznosile 7,64 $\pm 2,95 \mathrm{Bk} L-1,10,04 \pm$ 3,43 Bk L-1 i 69,04 $\pm 15,49$ Bk L-1 za 238U, 232Th I 40K respektivno. Transfer faktor iz tla u hranu za 238U, 232Th i 40K je izračunat na osnovu koncentracija aktivnosti zemljišta i hrane, dok su srednje vrednosti iznosile 0,73, 0,61 i 0,39 respektivno, u ispitivanoj oblasti.

Ključne reči: radioaktivnost, otpadni metal, transfer faktor, gama spektrometrija, gamma-scout merač radioaktivnosti 